\title{
CONCENTRATION OF SOLUBLE SALTS IN COOLING WATER OF POWER PLANTS WITH BLOW DOWN RECIRCULATION
}

\author{
V. Z. Kochmarskii ${ }^{1}$, O. P. Kostiuk ${ }^{2}$, Y. Y. Filipovych ${ }^{2}$ \\ ${ }^{1}$ Physical and Technological Laboratory of Water Systems (PTLWS), National University of Water \\ Management and Environmental Engineering (NUWMEE), Rivne, Ukraine, \\ v.z.kochmarskii@nuwm.edu.ua \\ ${ }^{2}$ Department of Hydropower, Heat Power Engineering and Hydraulic Machines, \\ National University of Water Management and Environmental Engineering (NUWMEE), Rivne, \\ Ukraine,o.p.kostuk@nuwm.edu.ua; y.y.filipovych@nuwm.edu.ua \\ DOI: https://doi.org/10.20535/2218-930032021246548
}

The method for calculating the dynamics of concentration of soluble salts (tracers) using the assumption of their homogeneous distribution in the water volume of the circulated cooling system (CCS) under the conditions of recirculation of part of the purge water was proposed. The assumption of homogeneity of salt distribution is substantiated by the fact that the period of mixing of cold water $(C W)$ in CCS is equal to several hours, and the period of setting the concentration limits is calculated in tens of days. In this approximation the law of change of concentration of tracers in time from the moment of their supply in CCS in modes without and with recirculation of a part of purge water and without any processing is received.

It is shown that without recirculating treatment, recirculation of purge water increases the maximum salt concentration and the time to reach it. Attention is drawn to the fact that the flow rate consists of two parts: controlled and uncontrolled. When calculating the allowable amount of purge recirculation, it is necessary to use the value of the total purge flow. It is important to understand that the relative change in total purge is always less than the controlled one.

To obtain the cost of full purge, it is necessary to calculate its uncontrolled part. The procedure for calculating the uncontrolled purge is given in the paper. Since there are restrictions for of maximum allowable concentration $(M A C)$ on the concentrations of tracers in the CCS, the expressions obtained in this work are consistent with the requirements of the MAC and allow for a given degree of concentration of salts $\varphi$, to calculate the limit of recirculation flow. It is shown that the recirculation regime can be applied without additional measures for CCS with a low initial degree of salt concentration and low concentration in the feed water.

The proposed algorithm is used to predict the results of recirculation in the case of a specific CCS for thermal power plants with an electrical capacity of $1200 \mathrm{MW}$ and the ratio $C_{M A C} / C_{0}=5$. It is shown that in this case recirculation has significant economic and environmental effects. However, at high, concentrations of tracers $C_{0}$, compared to MAC, feed water recirculation is meaningless.

The calculation algorithm applies to tracers, i.e. salts that do not give deposits, but only limited by the MAC requirements and the risk of corrosion or environmental considerations. Therefore, the above technique cannot be directly used for sparingly soluble salts, such as calcium carbonate. In this case, it requires significant correction.

Note the convenient use in calculations of the earlier introduced by us concept of regime (dynamic) factor $\varphi$, especially when comparing the real consumption of the main flows of CCS to calculated 
and in determining the evaporative capacity of cooling towers, or assessing the degree of salt concentration.

Keywords: circulating water, soluble salts, concentration, blow down make up period, recirculation

\section{Introduction}

Large volumes of blow down water discharges from circulating cooling systems (CCS) of enterprises, power plants in particular (Abramov, 1982; Kucherenko, 1980; Zalogin, 1979), under conditions of a shortage of fresh water and a temperature of discharges increased by $5 \div 15{ }^{\circ} \mathrm{C}$ often violate the local ecological balance. The salt content of the waste water is always 3-7 times higher than the initial make-up water, and the concentration of impurities in the discharges is higher than the MAC for surface waters, which entails severe restrictions on discharges and the corresponding penalties for enterprises. This situation leads to loss of profit and competitiveness. To plan blow down discharges, to minimize it, a mathematical model of the concentration of salts in circulating water is necessary that is adequate to the real situation and quite simple from the point of view of calculations. When modeling the modes of operation of the CCS, a steady regime is mainly adopted, which corresponds to the uniform distribution of the components of the cooling water $(\mathrm{CW})$ along the entire circulation path and the constancy of the operating parameters of the CCS, including its water volume, which does not always correspond to reality.

One of the ways to reduce the volume of CCS blow down is its partial return after cooling to the circulating water, i.e. recirculation. But then the concentration of soluble salts increases, increasing the total salt content of $\mathrm{CW}$ which can exceed the MAC for CW components (Kochmarskii, 2018). Therefore, the restrictions on the recirculation consumption associated with this must also be taken into account when creating the CCS mathematical model and estimating the consequences of recirculation.

\section{Problem statement}

The dynamic scheme for calculating the concentrations of highly soluble salts of chlorides, sulfates or others is considered in this work. Further these soluble salts will be called tracers (Andronov, 2006; Kucherenko, 1980). Accept that part of blow down returns into the circulating cycle without any processing.

Changes in the concentrations of tracers.in the circulating water of the CCS with cooling towers are observed depending on the modes of its operation. The admissible consumption of recirculation of a part of the blow down is estimated, depending on the initial state of the CW and restrictions on the MAC.

The mode of operation of the CCS is determined, see Fig. 1, by the concentration of soluble salts $\mathrm{C}_{0}$ in the make-up water, $\mathrm{C}_{\mathrm{r}}$ in the circulating water, the value of the circulating consumption $\mathrm{G}_{0}$, the make-up $\mathrm{G}_{\mathrm{mu}}$ the controlled part of the blow down $\mathrm{G}_{\mathrm{bd}}$, the evaporation flows $G_{e v}$, filtration $G_{f}$ and droplet entrainment $G_{d}, m^{3} / h$. 


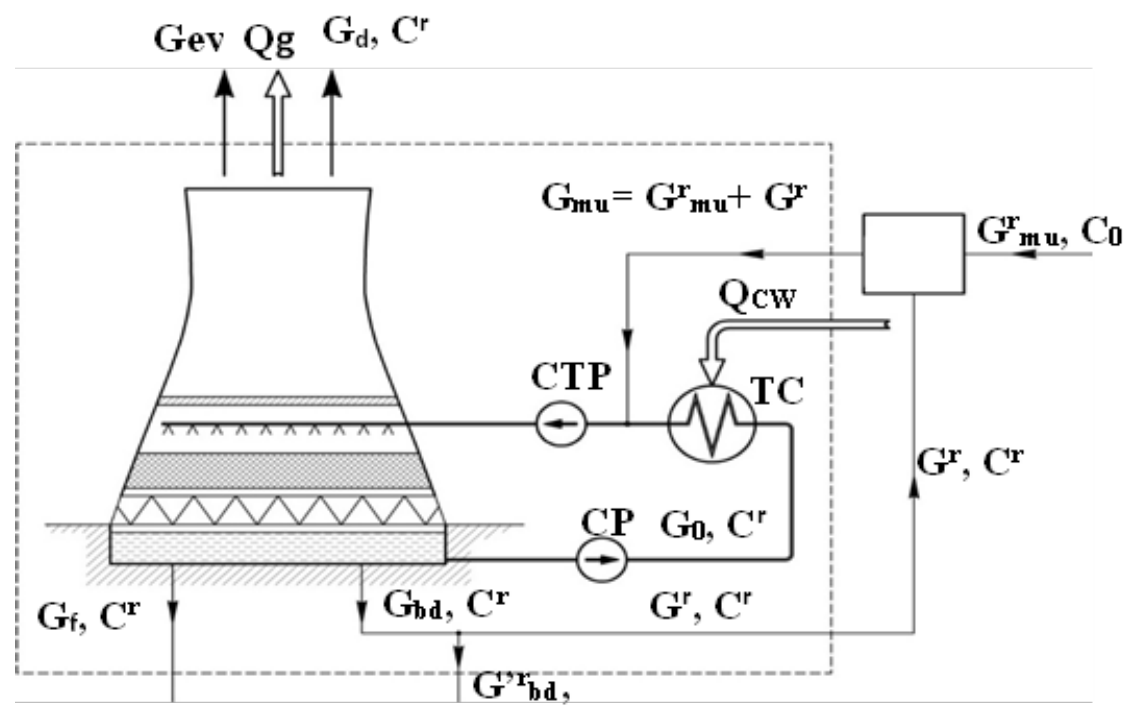

Fig. 1. Diagram of CCS with a cooling tower. The dashed line denotes the border of the CCS with the environment. The flows $\boldsymbol{G}_{\boldsymbol{e}}, \boldsymbol{G}_{\mathrm{g}}, \boldsymbol{G}_{\boldsymbol{d}}, \boldsymbol{G}_{\boldsymbol{m}}, \boldsymbol{G}_{\boldsymbol{b d}}, \boldsymbol{G}^{r}, \boldsymbol{G}_{\boldsymbol{m}}$ represent the interaction with the environment. TC, $\boldsymbol{C P}$ and $\boldsymbol{C T P}$ - turbine condenser, circulation pumps and cooling towers pump

Note that $\mathrm{CW}$ consumption for evapora-tion actually does not depend on CCS operation mode (with or without recirculation) and it is determined by the environment and power plant electric load.

\section{Models of CCS operation}

\section{modes}

The calculation will be made in the approximation of complete mixing of water in CCS, the latter, by the way, is close to the real situation, since the period of water circulation in CCS (mixing) is 1-2 hours, and the period of change in the concentrations of tracers in real systems is tens of days (Kucherenko, 1980).

The diagram of CCS with a cooling tower is shown in fig. 1. Salt entrainment from the circulating water of the CCS is carried out by the following flows: G'bd controlled blow down, Gr, Gmu and Gev, the lines of which in Fig. 1 cross the boundaries of the CCS, i.e. the total blow down flow is equal to

$$
G_{b d}=G^{\prime r}{ }_{b d}+G^{r}+G_{f}+G_{d},
$$

the index "r" denotes values in recirculation mode.

Filtration $\mathrm{G}_{\mathrm{f}}$ and droplet entrainment $\mathrm{G}_{\mathrm{d}}$ flows represent an uncontrolled part of the blow down and depend on the structure and design of the CCS elements and slightly on the mode of its operation. Estimates of the values of these fluxes (Abramov, 1982;Zalogin, 1979,Kucherenko, 1980) are $\mathrm{G}_{\mathrm{f}}$ $=(0.003 \ldots 0.007) \%$ of $\mathrm{G}_{0}$, and $\mathrm{G}_{\mathrm{d}}=(0.05 \ldots$ $0.10) \%$ of $\mathrm{G}_{0}$. Denote

$$
\mathrm{G}^{\prime \prime}{ }_{b d}=G_{f}+G_{d}
$$

then:

$$
\mathrm{G}_{\mathrm{bd}}=\mathrm{G}^{\prime \mathrm{r}}{ }_{\mathrm{bd}}+\mathrm{G}^{\mathrm{r}}+\mathrm{G}^{\prime}{ }_{\mathrm{bd}}=\mathrm{G}^{\mathrm{r}} \mathrm{bd}+\mathrm{G}^{\mathrm{r}} .
$$

In the operation mode of the CCS with recirculation of a part of the blow down water without its processing, the dynamics of the concentration of tracers in the circulating water in the approximation of complete mixing in the CCS is given by the equation concentration in g-ion $/ \mathrm{m}^{3}$.

$$
\frac{\mathrm{dM}_{\mathrm{r}}}{\mathrm{dt}}=\mathrm{C}_{0} \cdot \mathrm{G}_{\mathrm{mu}}^{\mathrm{r}}-\mathrm{C}_{\mathrm{r}} \cdot \mathrm{G}_{\mathrm{bd}}^{\mathrm{r}}, \mathrm{M}_{\mathrm{r}}=\mathrm{V} \cdot \mathrm{C}_{\mathrm{r}} \text {. }
$$


In order to obtain the closed equation relative to $\mathrm{C}_{\mathrm{r}},(2)$ must be supplied with the equation of dynamics of water volume $\mathrm{V}$.

$$
\frac{\mathrm{dV}}{\mathrm{dt}}=\mathrm{G}_{\mathrm{mu}}^{\mathrm{r}}+\mathrm{G}^{\mathrm{r}}-\mathrm{G}_{\mathrm{bd}}^{\mathrm{r}}-\mathrm{G}_{\mathrm{ev}} \text {. }
$$

Using (1a) and (3), we find the equation of the dynamics of tracers for the CCS operation with blow down recirculation without restrictions on the stationarity of CCS operation mode (Andronov, 2006; Repin, 2009).

$$
\begin{gathered}
\frac{\mathrm{dC}_{\mathrm{r}}(\mathrm{t})}{\mathrm{dt}}=\frac{1}{\mathrm{~T}_{\mathrm{bd}}^{\mathrm{r}}(\mathrm{t})} \cdot\left[\varphi^{\mathrm{r}}(\mathrm{t}) \cdot \mathrm{C}_{0}-\mathrm{C}_{\mathrm{r}}(\mathrm{t})\right] \\
\mathrm{T}_{\mathrm{bd}}^{\mathrm{r}}(\mathrm{t})=\frac{\mathrm{V}(\mathrm{t})}{\mathrm{G}_{\mathrm{bd}}^{\mathrm{r}}(\mathrm{t})} \\
\varphi^{\mathrm{r}}(\mathrm{t})=\frac{\mathrm{G}_{\mathrm{mu}}^{\mathrm{r}}(\mathrm{t})}{\mathrm{G}_{\mathrm{mu}}^{\mathrm{r}}(\mathrm{t})-\mathrm{G}_{e v}(\mathrm{t})} \cdot
\end{gathered}
$$

$\mathrm{T}^{\mathrm{r}} \mathrm{bd}(\mathrm{t})$ is the period of emptying the CCS by the blow down consumption in the recirculation mode, hours; $\varphi^{\mathrm{r}}(\mathrm{t})$ - dynamic (mode) parameter of the CCS.

It was taken into account in (4), that the value of water consumption for the evaporation $\mathrm{G}_{\mathrm{ev}}$ does not depend on the presence of recirculation and is the same in both modes of CCS operation.

Without recirculation, the equation for the dynamics of tracers is similar to (4), only in expressions (1) - (4) one should adopt $\mathrm{G}^{\mathrm{r}}=0$ and let pass the index $\mathrm{r}$.

If the CCS parameters $\varphi, \mathrm{T}^{\mathrm{r}}$ bd and $\mathrm{C}_{0}$ are slightly changed in time, then equations (4) are integrated and we obtain explicitly the laws of change in the concentration of tracers after the start of their supply $(\mathrm{t}=0)$ to the CCS,

$$
\begin{aligned}
& \mathrm{C}_{\mathrm{r}}(\mathrm{t})=\mathrm{C}_{0} \cdot\left[\varphi^{\mathrm{r}}-\left(\varphi^{\mathrm{r}}-1\right) \cdot \mathrm{e}^{-\frac{\mathrm{t}}{\mathrm{T}_{\mathrm{r}}^{\mathrm{r}}}}\right] \\
& \mathrm{C}_{\mathrm{r}}(\infty)=\varphi^{\mathrm{r}} \cdot \mathrm{C}_{0}
\end{aligned}
$$

From expressions (5) we find the physical content of the $\varphi^{\mathrm{r}}$ and $\mathrm{T}^{\mathrm{r}}$ bd parameters. The $\varphi^{\mathrm{r}}$ parameters in the steady-state mode of operation of the CCS represent the degree of concentration of tracers, and the $\mathrm{T}^{\mathrm{r}} \mathrm{bd}$ parameters describe the laws of changes in the concentration of tracers in time. The maximum possible value of $\varphi$ is determined by

$$
\max \varphi=\frac{\lim }{\mathrm{G}_{\mathrm{bd}}^{\prime \prime} \rightarrow 0}\left(\frac{\mathrm{G}_{\mathrm{mu}}}{\mathrm{G}_{\mathrm{bd}}^{\prime}+\mathrm{G}_{\mathrm{bd}}^{\prime \prime}}\right)=\frac{\mathrm{G}_{\mathrm{mu}}}{\mathrm{G}_{\mathrm{bd}}^{\prime}}
$$

Quite different than (4), a method for determining the value of the operating (dynamic) parameter $\varphi$ is given in (Gajevskii, Kochmarskii, 2018), where $\varphi$ is compared with the concentration coefficient of chlorides $\mathrm{k}_{\mathrm{Cl}}=\mathrm{C}_{\mathrm{Cl}} / \mathrm{C}_{\mathrm{Cl} 1}$. It is shown in (Gajevskii, Kochmarskii, 2018) that in the dynamic mode of CCS operation, the difference between these values is significant. Using the concept of the dynamic parameter $\varphi$, we estimate, at $\mathrm{V}=$ Const, the water consumption for evaporation and blow down consumption, taking the measured make-up consumption as the basis,

$$
\begin{gathered}
\mathrm{G}_{\mathrm{ev}}=\mathrm{G}_{\mathrm{mu}}-\mathrm{G}^{\prime}{ }_{\mathrm{bd}}-\mathrm{G}^{\prime}{ }^{\prime}{ }_{\mathrm{bd}}=(\varphi-1) \cdot \mathrm{G}_{\mathrm{mu}} / \varphi ; \\
\mathrm{G}_{\mathrm{bd}}=\mathrm{G}_{\mathrm{ev}} /(\varphi-1) .
\end{gathered}
$$

Expression (7) determines the total blow down according to (1) taking into account its uncontrolled part. The value of $\mathrm{G}_{\mathrm{ev}}$ obtained in (7) is free from any assumptions about the mechanism of evaporation or the design of coolers and represents, under the previously indicated restrictions, the value of the evaporative capacity of the cooling tower. This information can be useful for in-line control of the efficiency of cooling towers or CCS in general (Gajevskii, Kochmarskii, 2018). 


\section{Comparison of the CCS} operation modes with and without recirculation

Between the parameters $\varphi, \mathrm{T}_{\mathrm{bd}}$ and $\varphi^{\mathrm{r}}$, $\mathrm{T}_{\mathrm{bd}}$, see (4) and (4a), there are one-to one correspondences that allow, having $\varphi$ for the CCS operation mode without recirculation, to calculate the expected $\varphi^{\mathrm{r}}$ in the recirculation mode, and thus to evaluate the consequences recirculation,

$$
\varphi^{\mathrm{r}}=\frac{\varphi-(\varphi-1) \cdot \frac{\mathrm{G}^{\mathrm{r}}}{\mathrm{G}_{\mathrm{ev}}}}{1-(\varphi-1) \cdot \frac{\mathrm{G}^{\mathrm{r}}}{\mathrm{G}_{\mathrm{ev}}}}
$$

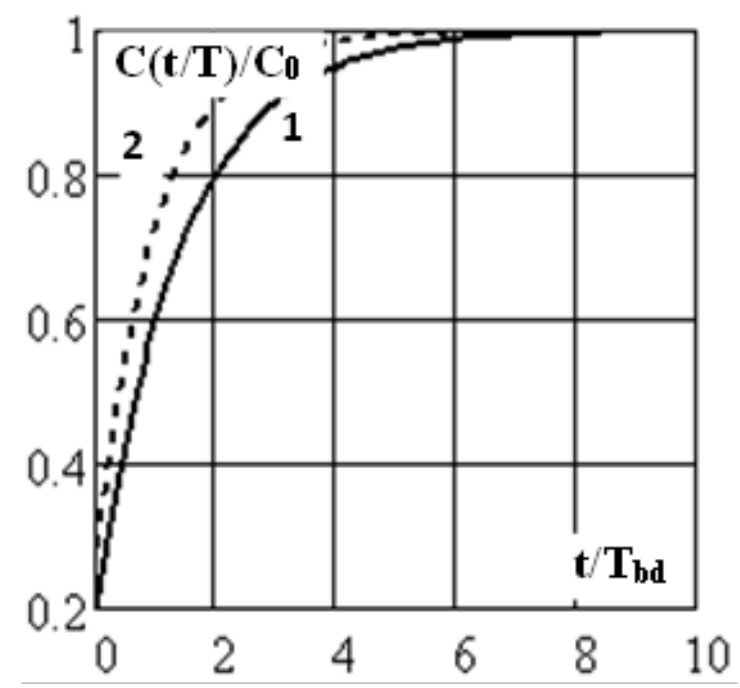

Fig. 2. Dependence of the concen-tration ratio in the mode with and without recirculation on the relative time from the beginning of the tracer supply to the CCS

One can see from Fig. 2 and 3 that the concentration of tracers in the CCS with recirculation reaches equilibrium approximately $8 \mathrm{~T}_{\mathrm{bd}}$ later than without recirculation. When calculating the curves in Fig. 2 and 3, it is assumed that: $\varphi=4, \varphi^{\mathrm{r}}=5.3$, recirculation consumption according to (12), $\mathrm{G}^{\mathrm{r}}=0.1 \mathrm{G}_{\mathrm{ev}}$. As it follows from (8), the parameter $\varphi^{\mathrm{r}}$ also increases in comparison

$$
\mathrm{T}_{\mathrm{bd}}^{\mathrm{r}}=\frac{\mathrm{T}_{\mathrm{bd}}}{1-(\varphi-1) \cdot \frac{\mathrm{G}^{\mathrm{r}}}{\mathrm{G}_{\mathrm{ev}}}} .
$$

It follows from (8) that the expected $\varphi^{\text {r, }}$ i.e. the characteristics of the degree of concentration of tracers in the recirculation mode depends on the ratio of the recirculation and evaporation consumption $\mathrm{G}^{\mathrm{r}} / \mathrm{G}^{\mathrm{ev}}$. Comparing (4) and (8), we find that recirculation increases the make-up time $\mathrm{T}^{\mathrm{r}} \mathrm{bd}$ i.e. the time to reach the limiting saturation of $\mathrm{CW}$ tracers in the CCS with recirculation is longer than in the usual mode, see Fig. 2 and 3 , as well as expressions (5).

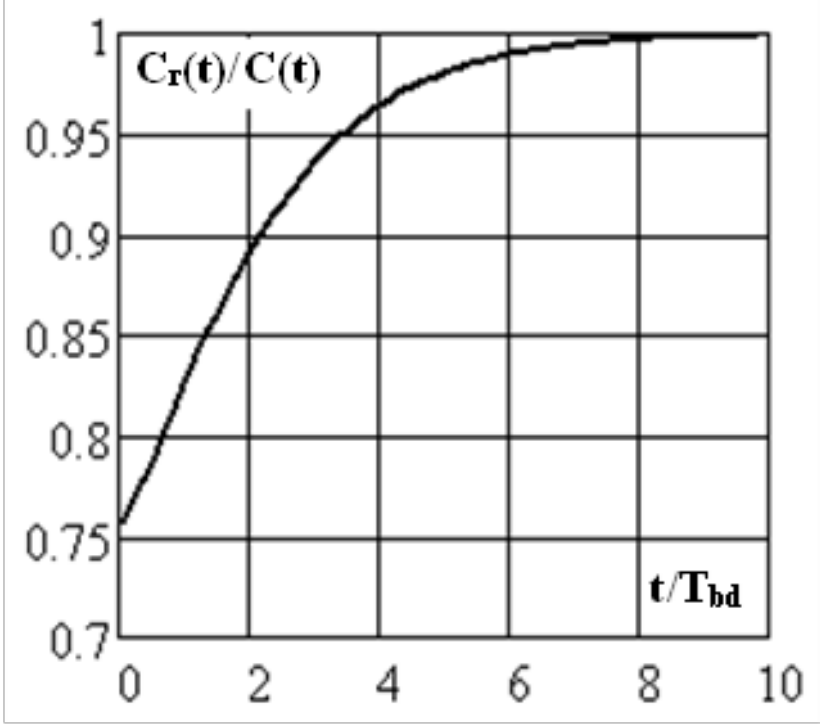

Fig. 3. Dependence of concentration ratio in the mode with and without recirculation on the relative time from the begin

with the initial $\varphi$ (mode without recirculation), see Fig. 3. We see that the relative growth of $\varphi^{\mathrm{r}}$ increases with the growth of the initial $\varphi$, which must be taken into account when considering the restrictions associated with the LAC of salts. It is also necessary to take into account that the quantities $\varphi$ and $\varphi^{\mathrm{r}}$ cannot take arbitrary 
values, since the positive definiteness of $\varphi^{\mathrm{r}}$, see $(8)$, requires that

$$
\mathrm{G}^{\mathrm{r}}<\frac{\mathrm{G}_{\mathrm{ev}}}{\varphi-1},
$$

This condition, if we take into account that $\mathrm{G}_{\mathrm{ev}} /(\varphi-1)=\mathrm{G}_{\mathrm{bd}}$, see (1a), becomes obvious and expresses the fact that the recirculation flow is part of the total blow down. In both cases (with or without recirculation) the maximum values of $\varphi$ and $\varphi p$ must satisfy the ecological condition

$$
\max \varphi=\max \varphi^{\mathrm{r}}<\mathrm{C}_{\mathrm{LAC}} / \mathrm{C}_{0} .
$$

$\mathrm{C}_{\text {MAC }}$ is the MAC of tracers in $\mathrm{CW}$.

We use formulas (8) and (9) to solve the inverse problem: find the maximum value of $\mathrm{G}^{\mathrm{r}} / \mathrm{G}_{\mathrm{ev}}$ for a given $\varphi$, such one that $\max \varphi^{\mathrm{r}}<\mathrm{C}_{\mathrm{MAC}} / \mathrm{C}_{0}$

$$
\frac{\mathrm{G}^{\mathrm{r}}}{\mathrm{G}_{\mathrm{ev}}}<\frac{\mathrm{C}_{\mathrm{MAC}}-\mathrm{C}_{0} \cdot \varphi}{(\varphi-1) \cdot\left(\mathrm{C}_{\mathrm{MAC}}-\mathrm{C}_{0}\right)} .
$$

Ratio (11) establishes a range of possible values of recirculation consumption, agreed with the requirement of restrictions on MAC (10) (Gajevskii, Kochmarskii, 2018),

$$
\begin{gathered}
0 \leq \mathrm{G}^{\mathrm{r}}<\max \mathrm{G}^{\mathrm{r}}, \\
\max ^{\mathrm{r}}=\mathrm{G}_{\mathrm{ev}} \cdot \frac{\mathrm{C}_{\mathrm{MAC}}-\mathrm{C}_{0} \cdot \varphi}{(\varphi-1) \cdot\left(\mathrm{C}_{\mathrm{MAC}}-\mathrm{C}_{0}\right)} .
\end{gathered}
$$

Note that restriction (11) is much stricter than (9). Indeed, (9) expresses only the fact that the recirculation consumption is a part of the total blow down, and (11) contains an additional condition (10), which requires the concentration of tracers in the CCS to be less than the corresponding MAC. From (11) we also find that for the modes of operation of the CCS with the initial $\varphi \approx \max \varphi$ (the initial mode without recirculation has a high degree of concentration), it makes no sense to use recirculation.

\section{Quantitative estimate}

Consider the CCS of Thermal Power Plant with a capacity of $\mathrm{Ne}=4 \times 300 \mathrm{MW}$ with a water volume of $\mathrm{V}=240000 \mathrm{~m}^{3}$ as an example of the application of the developed algorithm. Let us take the ratio $\mathrm{C}_{\mathrm{MAC}} / \mathrm{C}_{0}=5$, which corresponds to $\mathrm{C}_{0}=70 \mathrm{mg} / \mathrm{dm}^{3}$, and the initial value of the parameter $\varphi$ (in the steady state, the degree of concentration of tracers), we take $\varphi=3.5$. Then from (13) we obtain that $\operatorname{maxG}^{\mathrm{r}}=0.15 \mathrm{G}_{\mathrm{ev}}$. According to condition (11), let us take $G^{r}=300 \mathrm{~m}^{3} / \mathrm{h}$ and, using the algorithm for calculating the uncontrolled part of the blow down and the modes of operation of the CCS without and with recirculation (Kochmarskii et all), we obtain the main parameters of the CCS, the values of which are presented in Table 1.

Note that the blow down, evaporation and make-up consumption used in the calculation are mutually in agreement only in the steady state at $\mathrm{V}=$ Const. For other modes, the calculation may include an uncontrolled error, but for estimates, it is suitable beyond the specified restrictions.

It follows from table. 1 that the blow down recirculation under such conditions makes it possible to reduce the make-up consumption by $9 \%$, the total blow down by $33 \%$, and the controlled blow down by $38 \%$, which makes it possible to significantly reduce the cost of power generation. But recirculation, as it is shown in the table. 1, increases the total salt content of CW by $34 \%$ and brings the concentration of tracers close to the $\mathrm{MAC}\left(0.94 \mathrm{C}_{\mathrm{MAC}}\right)$.

Let us estimate the decrease in the amount of salts discharged into the environment. Since the degree of concentration of tracers in the recirculation mode is $34 \%$ higher than without 
recirculation, and the value of controlled blow down is $38 \%$ less, we find that the amount of dumped salts in the recirculation mode is $17 \%$ lower than without it.

Table 1. Comparison of CCS operation parameters with and without recirculation

\begin{tabular}{|c|c|c|c|c|c|c|}
\hline № & \multicolumn{2}{|c|}{ Parameters } & Units & $\begin{array}{c}\text { Without } \\
\text { recirculation }\end{array}$ & Recirculation & $\begin{array}{c}\text { Changes, } \\
\%\end{array}$ \\
\hline 1 & \multicolumn{2}{|c|}{ Make-up consumption, $\mathrm{G}_{\mathrm{mu}}$} & $\mathrm{m}^{3} / \mathrm{h}$ & 3220 & 2920 & -9.0 \\
\hline 2 & \multicolumn{2}{|c|}{ Evaporation consumption, $\mathrm{G}_{\mathrm{ev}}$} & $\mathrm{m}^{3} / \mathrm{h}$ & 2300 & 2300 & 0 \\
\hline \multirow{3}{*}{3} & \multirow{3}{*}{$\begin{array}{l}\text { Blow down } \\
\text { consumption: }\end{array}$} & total, $\mathrm{G}_{\mathrm{bd}}$ & $\mathrm{m}^{3} / \mathrm{h}$ & 920 & 620 & -33.0 \\
\hline & & controlled, $\mathrm{G}_{\text {bd }}$ & $\mathrm{m}^{3} / \mathrm{h}$ & 780 & 480 & -38 \\
\hline & & uncontrolled,G" bd & $\mathrm{m}^{3} / \mathrm{h}$ & 140 & 140 & 0 \\
\hline 4 & \multicolumn{2}{|c|}{ Recirculation consumption, $\mathrm{G}^{\mathrm{r}}$} & $\mathrm{m}^{3} / \mathrm{h}$ & 0 & 300 & - \\
\hline 5 & \multicolumn{2}{|l|}{ Coefficient $\varphi$} & - & 3.5 & 4.7 & +34 \\
\hline 6 & \multicolumn{2}{|l|}{ Ratio $\mathrm{C} / \mathrm{C}_{\mathrm{MAC}}$} & - & 0.7 & 0.94 & +24 \\
\hline 7 & \multicolumn{2}{|c|}{ Blow down period, $\mathrm{T}_{\mathrm{bd}}$} & hour & 260 & 386 & +48 \\
\hline
\end{tabular}

In conclusion, we note that the above algorithm for calculating the consequences of blow down recirculation applies only to tracers, i.e. non-depositing salts. As follows from the previous one, recirculation without processing can increase the concentration of calcium ions, and thus contributes to an increase in the growth rate of calcium deposits, as well as the consumption of reagents for the stabilization of $\mathrm{CW}$. Therefore, the problem arises of adapting this algorithm in relation to the analysis of changes in the concentration of salts undergoing phase transformations into $\mathrm{CW}$, and the development of methods for controlling their concentration and sediments under recirculation conditions.

\section{Conclusions}

The method for calculating the dynamics of salts concentration, using the assumption of their uniform distribution in the CCS volume was suggested. It is justified by the fact that the period of circulation (mixing) of $\mathrm{CW}$ in the CCS is equal to several hours, and the period of establishment of limiting concentrations is calculated in tens of days.
It is important to understand and remember that the blow down consumption consists of two parts: controlled $\mathrm{G}_{\text {bd }}$ and uncontrolled G" bd. When calculating the admissible blow down value $\mathrm{G}^{\mathrm{r}}$, see (13), total blow down is used. To obtain total blow down, it is necessary to calculate the uncontrolled part of it. To do this, you can use the procedure (Gajevskii, Kochmarskii, 2018). The relative change in the total blow down is always less than the controlled one, see table 1.

In the approximation of a uniform distribution of salts in the volume of the CCS, the law of the change in the concentration of tracers versus time was obtained from the moment they were fed into the CCS without and with recirculation of a part of the blow down water without processing, see (5).

Since there are restrictions on the concentrations of tracers in the CCS, expressions have been established that allow for the initial degrees of salt concentration $\varphi$ to calculate the limiting values of the recirculation of the blow down consumption $\max G^{r}$, see (13) and (Gajevskii, Kochmarskii, 2018). 
It was shown that the recirculation mode is applicable without additional measures for the CCS with a small initial degree of concentration. Recirculation under such conditions has significant economic and environmental effects, see table 1.

Note the convenience of using the concept of the operating (dynamic) factor $\varphi$, introduced by us earlier (Andronov, 2005; Kochmarskii at al., 2018), when determining the evaporative capacity of cooling towers or when estimating the degree of salt concentration.

The use of recirculation allows us not only to reduce the consumption of fresh water for make-up, but also to reduce the discharge of salts into the environment.

\section{References}

1. Abramov, N. N. Water supply; Moscow, Stroyizdat, 1982.

2. Zalogin, N. G.; Kropp, L. I.; Kostrikin, Y. M. Energy and environmental protection; Moscow, Energy, 1979.

3. Kucherenko, D. I.; Gladkov, V. A. Reverse water supply (Water cooling systems); M. Stroyizdat, 1980.
4. Kochmarskii, V. Z.; Trofymchuk, I. P. DP of Ukraine. No. 127744. The method of determining the concentration degree of soluble salts in water of circulating cooling systems with recirculation of blow down water. Bul. No. 16. 27.08.2018.

5. Andronov, V. A. Ecological safety systems and recirculating water supply of coke-chemical, metallurgical and machine-and-food enterprises; Author's abstract. dis. Doctor of Technical Sciences, Donetsk, 2006.

6. Repin, D. A. Optimization of water-chemical modes of cooling systems of turbine condensers; Author's ref. dis., Moscow, 2009.

7. Gajevskii, V. R.; Kochmarskii, V. Z. The efficiency increase of circulating cooling systems by minimizing calcium carbonate deposits. 2018.

8. Kochmarskii, V. Z., Trofymchuk, I. P.; Cuba, V. V. Peculiarities of the behavior of tracers and the solid $\mathrm{CaCO}_{3}$ formation in circulating cooling systems. Water and water purification technologies. Scientific and technical news 2018, 22(2), 39-49. https://doi.org/10.20535/2218-93002212018144242 


\title{
КОНЦЕНТРУВАННЯ РОЗЧИННИХ СОЛЕЙ У ВОДІ СИСТЕМ ОХОЛОДЖЕННЯ ЕЛЕКТРОСТАНЦЙ ПРИ РЕЦИРКУЛЯЦЇ̈ ПРОДУВКИ
}

\author{
Кочмарський В. 3. ${ }^{1}$, Костюк О. П. ${ }^{2}$, Філіпович Ю. Ю. ${ }^{2}$ \\ ${ }^{1}$ Фізико-технологічна лабораторія водних систем (ФТЛВС) Національного університету \\ водного господарства і природокористування (НУВГП), м. Рівне, Україна \\ ${ }^{2}$ Кафедра гідроенергетики, теплоенергетики і гідравлічних машин НУВГП, м. Рівне, Україна
}

\begin{abstract}
Запропоновано спосіб розрахунку динаміки конщентрування розчинних солей (трасерів) 3 використанням припущення про їх однорідний розподіл в об'ємі оборотної системи охолодження (ОСО) в умовах застосування рециркуляиії частини води продувки. Припущення про однорідність розподілу солей обтрунтоване тим, що період обігу (перемімування) охолодної води (OB) в ОСО дорівнює декільком годинам, а період встановлення граничних конщентрацій обчислюється десятками діб. У изьому наближенні отримано закон зміни концентрації трасерів від часу з моменту їх подачі в ОСО у режимах без та з рециркуляцією частини води продувки без ії обробки. Показано, щзо без обробки рециркулянта, рециркуляція води продувки збільшує граничну концентрацію солей та час ї̈ досягнення. Звертається увага на це, щуо витрата продувки складається з двох частин: контрольованої $і$ неконтрольованої. При розрахунках допустимої величини рециркуляціі продувки, необхідно використовувати величину повної витрати продувки. Важливо, розуміти, щзо відносна зміна повної продувки завжди менша ніж контрольованої. Для отримання витрати повної продувки необхідно розрахувати ї̈ неконтрольовану частину. Процедура розрахунку наводиться в роботі. Оскільки в ОСО існують обмеження щуодо концентрацій трасерів, то отримані вирази, щзо дозволяють для заданого ступеня концентрування солей щзо режим рециркуляиії можна застосовувати без додаткових заходів для ОСО з малим початковим ступенем концентрування солей та малою їх концентрацією уводі підживлення. На прикладі аналізу конкретної ОСО показано, щзо у иъьму випадку рециркуляція дає суттєві економічні та екологічні ефекти. Запропонований алгоритм прогнозування результатів рециркулячії без обробки води продувки стосується трасерів, тобто. солей, щзо не дають відкладень, а лише обмежених вимогами ГДК та небезпекою корозії чи екологічними міркуваннями. Зазначимо зручність використання при розрахунках, введеного нами раніме поняття режимного (динамічного) фактора ф, особливо при аналізі відповідності витрат основних потоків ОСО розрахунковим, при визначенні випарної здатності градирень або оцінці ступеня концентрування солей.
\end{abstract}

Ключові слова: оборотна (охолодна) вода, концентрування солей, розчинні солі, рециркулячія, період продувки, продувка 